\title{
Primary cutaneous extra-nodal NK-cell lymphoma, nasal type
}

\author{
Tadashi Terada* \\ Department of Pathology, Shizuoka City Shimizu Hospital, Shizuoka, Japan
}

Received: January 4, 2016

DOI: $10.5430 /$ crcp.v3n3p38
Accepted: May 9, 2016

Online Published: June 3, 2016

\begin{abstract}
Primary extra-nodal NK-cell lymphoma of skin is extremely rare. A 55-year-old man presented with an elevated plaque of trunk. The dermatologists' diagnosis was sporotrycosis and a biopsy was taken, which showed diffuse dense infiltrations of medium-sized and large atypical malignant lymphocytes. Epidermal hyperplasia and erosions were also seen. Immunohistochemically, the atypical lymphocytes were positive for CD45, CD56, CD57, p53 and Ki-67 (labeling index = 82\%). They were negative for CD20, CD79 $\alpha$, CD10, bcl-2, $\kappa$-light chain, $\lambda$-light chain, CD3, CD4, CD5, CD21, CD23, CD38, CD43, CD68, CD138, CD15, CD30, TdT, and cyclin D1. EBER was positive. The pathological diagnosis was primary cutaneous NK-cell lymphoma, nasal type. The post-biopsy blood test identified no leukemia findings. Post-biopsy imaginings revealed no mass and lymphadenopathy in the body. The skin lesions of the patient almost improved (complete remission) by chemotherapy (CHOP) followed by local radiation, and the patient is now followed up.
\end{abstract}

Key Words: Skin, NK-cell neoplasm, Histopathology, Immunohistochemistry

\section{INTRODUCTION}

Primary malignant lymphomas of skin are classified largely into the following 4 groups: mature T-cell and NK-cell neoplasms, mature B-cell neoplasms, immature hematopoietic malignancies, and Hodgkin's disease. ${ }^{[1,2]}$ Of these, NKcell neoplasms of skin are categorized into the following two types: extra-nodal NK-cell lymphoma, nasal type, and blastic NK-cell lymphoma. The extra-nodal NK/T-cell lymphoma, nasal type, is defined as an Epstein-Burr virus (EBV) positive extra-nodal lymphoma consisting of small, medium or large cells usually with NK-cell phenotype, T cell phenotype, and both. Therefore, this category has been known usually as cutaneous extra-nodal NK/T cell lymphoma, nasal type; however, the pure NK cell lymphomas without T-cell markers are rare. In these NK/T cell lymphomas, skin is the second most common site of involvements after naso-pharynx, and skin involvement may be a primary or secondary manifestation of the disease. ${ }^{[3]}$ The NK/T cell lymphomas, nasal type, have been reported several times, ${ }^{[4-15]}$ but pure extra-nodal cutaneous NK-cell, not T-cell, lymphoma, nasal type, is rare. In a Japan nationwide study of 1,733 patients. with cutaneous lymphomas, only 34 cases (2\%) were of cutaneous NK/Tcell lymphoma. ${ }^{[16]}$ Herein reported is a rare case of primary cutaneous extra-nodal pure NK-cell lymphoma, not T-cell lymphoma, nasal type.

\section{Case report}

A 55-year-old man consulted to Dermatolog clinic of our hospital because of elevated plaque measuring $4 \mathrm{~cm} \times 5 \mathrm{~cm}$ in the trunk (abdomen). No other tumors were seen in the skin

\footnotetext{
*Correspondence: Tadashi Terada, MD, PhD; Email: piyo0111jp@yahoo.co.jp; Address: Department of Pathology, Shizuoka City Shimizu Hospital, Miyakami 1231 Shimizu-Ku, Shizuoka 424-8636, Japan.
} 
and there was no lymph-node swelling. A dermatologists' diagnosis was sporotrycosis and a biopsy was taken.

The biopsy showed diffuse dense infiltrations of mediumsized to large atypical lymphocytes (see Figures 1A-C). The proliferation was monotonous and no follicular structures were noted. The histological features were apparently those of malignant lymphoma. HE, PAS, and Grocott stainings revealed no fungi. Mitotic figures were noted in places (see Figure $1 C$ ); the density of them was $12 / 10$ HPFs. The epidermal hyperplasia and erosions were also seen (see Figure 1A).

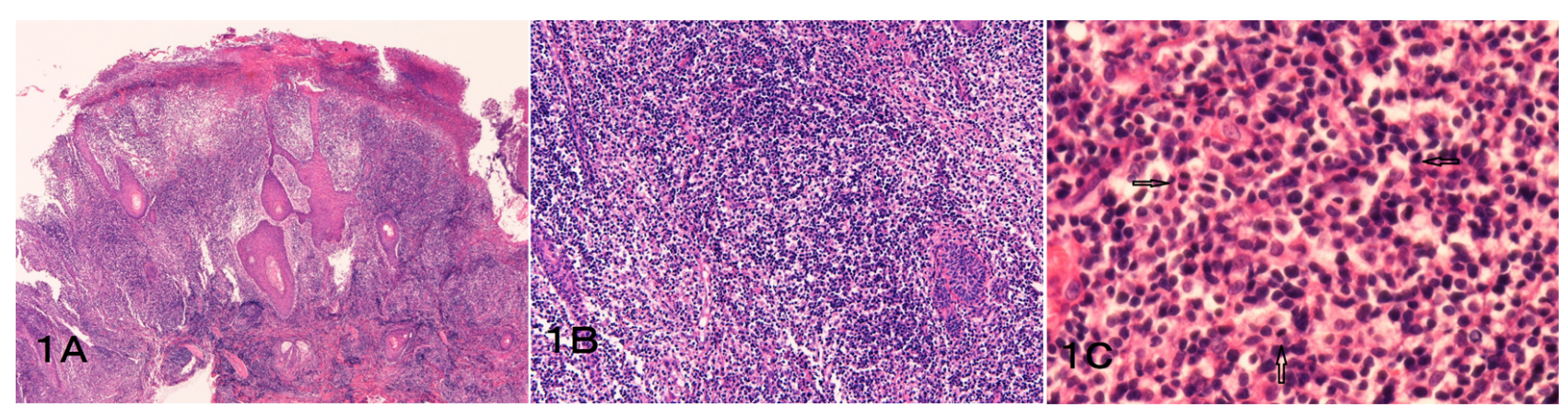

Figure 1. Histopathologic features of the skin lesion of trunk

A: Very low power view of the skin lesion. Dense infiltrations of medium-sized to large atypical lymphocytes and cutaneous erosion and hyperplasia are seen. $H E, \times 20$. B: Medium magnification shows atypical large lymphocytes. $H E, \times 400$.

C: High power view showed atypical features of lymphocytes and mitotic figures (arrows). HE, $\times 200$.
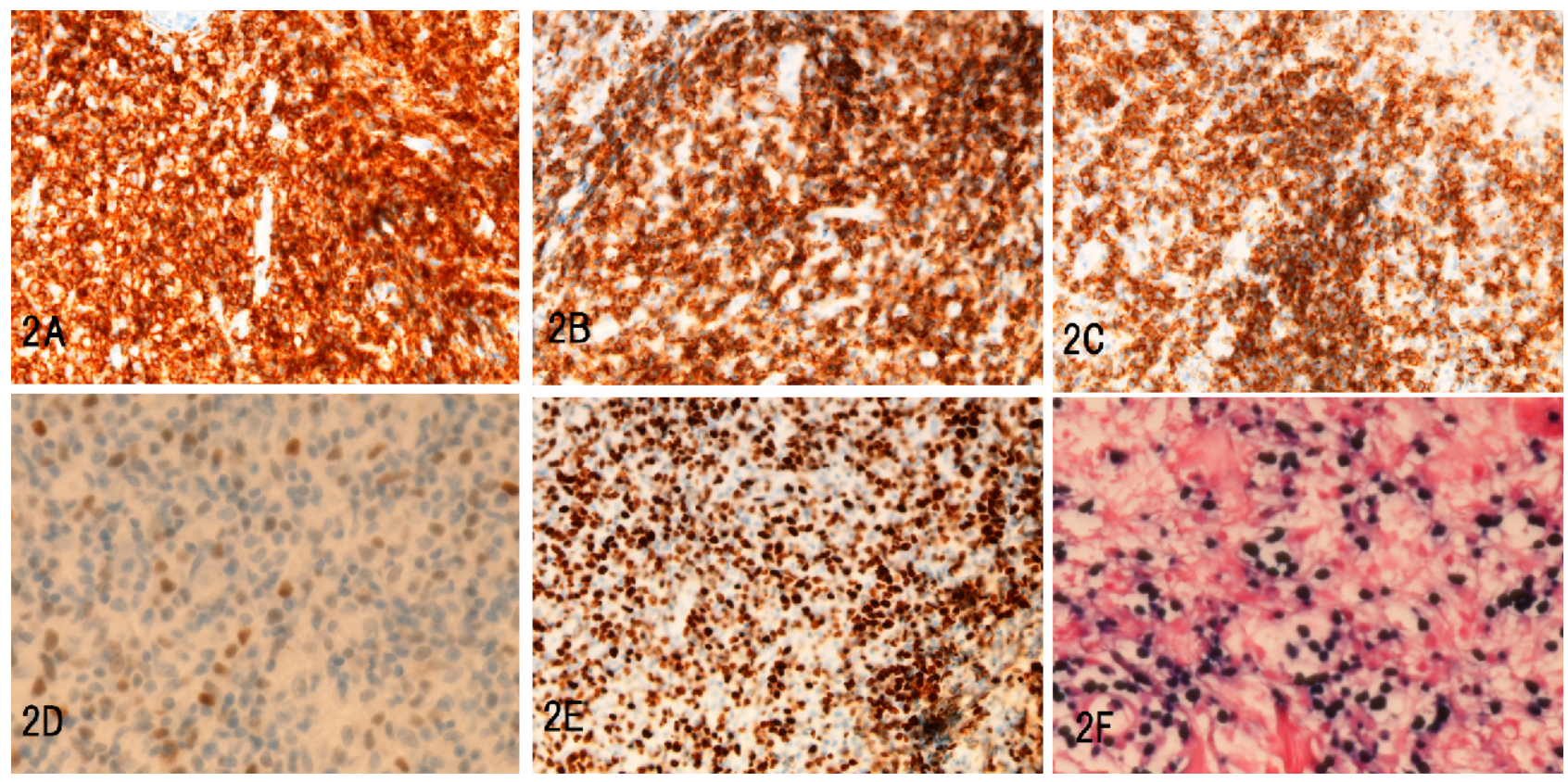

Figure 2. Immunohisochemical and in situ hybridization findings

The atypical lymphocytes were positive for CD45 (A), CD56 (B), CD57 (C), p53 (D), and Ki-67 (labeling index $=82 \%)(E)$. In situ hybridization for EBV encoded RNA (EBER) was positive $(F)$. A-F, $\times 200$.

An immunohistochemical study was performed with the use of Dako Envision method, as previously reported. ${ }^{[17,18]}$ The atypical small lymphocytes were positive for vimentin, CD45 (see Figure 2A), CD56 (see Figure 2B), CD57 (see Figure 2C), p53 (see Figure 2D), Ki-67 (labeling index $=82 \%$ ) (see Figure 2E), and Epstein-Barr virus (EBV) encoded la- tent membrane protein-1 (LMP-1). They were negative for CD20, CD79 $\alpha, \mathrm{CD} 10$, bcl-2, $\kappa$-light chain, $\lambda$-light chain, CD3, CD4, CD5, CD21, CD23, CD38, CD43, CD68, CD138, CD15, CD30, TdT, cyclin D1, various types of cytokeratins, and EMA. In situ hybridization for EBV encoded small RNA (EBER) was performed, as previously reported, and the tu- 
mor cells were positive for EBER (see Figure 2F).

Immunohistochemical interpretations: CD45 is positive in varieties of leukocytes. CD56 (aka NCAM) and CD57 are markers for NK cells in lymphoid population, but CD56 is positive also in neuroendocrine cells. CD3, CD4, and CD5 are among T-cell antigens. CD21 and CD23 are among dendritic markers. CD20 and CD79 $\alpha$ are markers of B-cells, while light chains, CD38, CD138 imply plasma cell differentiation. The present case was $\kappa$-light chain (-), $\lambda$-light chain $(-)$, suggesting no plasma cell differentiation. Light chain restriction is non-sense because the case was NK cell lymphoma. CD68 is a histiocytic marker. In situ hybridization of EBER and immunoexpression of LMP-1 indicate EBV infection. Tp53 was positive and it shows p53 gene mutations which give rise to long half-time mutant p53. Ki67 labeling is very high (82\%), suggesting very high cells proliferation of the tumor. CD30 and CD15 are expressed in immunoblastic tumor, Hodgekin's lymphomas, and ATLL. TdT marks early lymphoid differentiation and therefore B-lymphoblastic and T-lymphoblastic lymphomas.

The pathological diagnosis was primary cutaneous pure NKcell lymphoma, nasal type. The post-biopsy blood test identified no leukemia findings. Post-biopsy imaginings revealed no mass and lymphadenopathy in the body. It was concluded that the stage of the lymphoma was Ann Arbor Stage 1. The skin lesions of the patient almost cured (complete remission) by chemotherapy (CHOP) followed by local irradiation (30 gray), and the patient is now followed up.

\section{Discussion}

Because no other mass was seen in the body by various imaging techniques, the present cutaneous lesion is primary cutaneous neoplasm. The lesion is a malignant lymphoma because atypical features including mitotic figures were seen and also because p53 was positive and Ki-67 labeling index was very high. The cutaneous tumor was NK-cell neoplasm because NK-lymphocyte makers (CD56 and CD57) were positive but B-cell and T-cell markers were negative.

The present tumor was positive only for CD56, CD57, p53, Ki67 (82\%), LMP-1, and ERER (in situ hybridization). CD56 and CD57 are recognized antigens of NK cells, and are specific for NK cells in lymphoid tissues. The p53 was positive, suggesting positive p53 gene mutations. The Ki-67 was very high, indicating a high cell turn over in the tumor. That is, the present tumor did not show any lineages of B, T, plasma cells, Hodgkin cells, ALCL, lymphoblastic lymphoma; therefore the case fulfills the diagnostic criteria of primary cutaneous NK-cell lymphoma. Because the tumor lacked T-cell antigens, the case is not primary cutaneous
NK/T cell lymphoma, nasal type, but primary cutaneous NK cell lymphoma, a rare tumor.

According to WHO criteria, ${ }^{[19,20]}$ NK-cell neoplasms were classified into the following four types: extra-nodal NK-cell lymphoma, nasal type, blastic NK-cell lymphoma, chronic lymphoproliferative disorders of NK cells, and aggressive NK-cell leukemia. ${ }^{[1-4,18,19]}$ The latter two are leukemia. The present case is not chronic lymphoproliferative disorder of NK-cell or aggressive NK-cell leukemia, because it showed no leukemic features. The present case is not blastic NKcell lymphoma, because it showed no aggressive course and no features of blastic lymphocytes. It also was negative for CD4, suggesting that the present case is not blastic NK-cell lymphoma. The case fulfills the WHO criteria of extra-nodal NK-cell lymphoma, ${ }^{[1-15]}$ a rare disorder.

Extranodal NK/T cell lymphoma is rare in western country but relatively common in the east-Asia where EBV infection is prevalent. ${ }^{[1-15]}$ The disease affect mainly male with a M:F ratio of about $2: 1 .^{[11-15]}$ The disease is commonly seen in middle-aged persons with a median of 46 years. This type of lymphoma is mainly seen in upper aerodigestive system followed in order by skin and digestive organs etc. Most of the patients were in Ann Arbor Stage 1 or 2, while 30\% in Ann Arbor Stage 3 or 4 . About $20 \%$ show lympho-adenopathy and bone marrow involvements. Characteristic histological features are angiocentric/angiodestructive growth pattern in addition to obvious lymphoma features. The lymphoma cells show a wide spectrum of histological features: medium sized $(n=34)$, mixed small and large $(n=21)$, large $(n=13)$, and small $(n=5)$. EBER is, by definition, positive in every case. Immunohistochemical studies show CD3 and CD56 expression in more than $90 \%$ of cases. Ki-67 labeling index tends to be very high: $\mathrm{Ki}-67$ labeling index was $\geq 60 \%$ in about $50 \%$ of cases. The methods of therapy are not established because of the rarity of this lymphoma, and they depends on the stages. According to the 64 patients of NK/T lymphoma; ${ }^{[12]}$ 14 received only chemotherapy, 8 radiation alone, and 42 received combined radiation and chemotherapy. The survival is not good with the median survival around 4 years, and 5-year overall survival was about 50\%. Extra-nasal disease, advanced stage, and high $\mathrm{Ki}-67$ proliferation rate seem to correlate with poorer prognosis.

In conclusion, the author reported a very rare case of primary cutaneous pure extra-nodal NK-cell lymphoma, nasal type, associated with EBV, with an emphasis on histological, Immunohistochemical, HBV viral in situ hybridization features.

\section{Conflicts of Interest Disclosure}

The author has no conflict of interest.

ISSN 2331-2726 E-ISSN 2331-2734 


\section{REFERENCES}

[1] Harris NL, Stein H, Campo E, et al. Introduction to the WHO classification of tumours of haematologic and lymphoid tissues. In: Swerdlow SH, Campo E, Harris NL, Jaffe ES, Pileri SA, Stein H, Thiele J, Vardiman JW eds. WHO classification of tumours of haematologic and lymphoid tissues. Lyon: IARC Press; 2008. 14p.

[2] Burg G, Diaz-Perez JL, Ralfkiaer E, et al. WHO/EORTC Classification of cutaneous lymphomas. In: LeBoit FE, Burg G, Weedon D, Sarasin A eds. World Health Organization of Tumours. Pathology and genetics of skin tumour. Lyon: IARC Press; 2006. 166p.

[3] Kohler S, Iwatsuki K, Jaffe ES, et al. Extranodal NK/T cell lymphoma, nasal type. In: LeBoit FE, Burg G, Weedon D, Sarasin A eds. World Health Organization of Tumours. Pathology and genetics of skin tumour. Lyon: IARC Press; 2006. 191p.

[4] Sander CA, Kazakof DV, Jaffe ES, et al. Blastic NK-cell lymphoma. In: LeBoit FE, Burg G, Weedon D, Sarasin A eds. World Health Organization of Tumours. Pathology and genetics of skin tumour. Lyon: IARC Press; 2006. 208p.

[5] Szu LDC, Ping CY, Yee LH, et al. Test and teach. An unusual cause of nodular skin lesions with ulcer. Diagnosis: Cutaneous extranodal NK/T-cell lymphoma, nasal type. Pathology. 2008; 40: 714-8. PMid: 18985527. http://dx.doi.org/10.1080/00313020802 441691

[6] Peck T, Wick MR. Primary cutaneous natural killer/T-cell lymphoma of the nasal type: a report of 4 cases in North American patients. Ann Diagn Pathol. 2015; 19: 211-5. PMid: 25952095. http: //dx.doi.org/10.1016/j.anndiagpath.2015.04.003

[7] Charli-Joseph Y, Saeb-Lima M, Hernández-Salazar A, et al. Nasaltype extranodal natural killer/T-cell lymphoma presenting as genital ulcers. J Am Acad Dermatol. 2012; 67: 157-9. PMid: 22980279. http://dx.doi.org/10.1016/j.jaad.2011.12.031

[8] McKelvie PA, Thompson PA, Tam CS. Peripheral T cell and natural killer (NK) T cell lymphomas: a clinicopathological study from a single Australian centre. Histopathology. 2012; 61: 212-23. PMid: 22716228. http://dx.doi.org/10.1111/j.1365-2559. 2012 $.04238 . x$

[9] Zuriel D, Fink-Puches R, Cerroni L. A case of primary cutaneous extranodal natural killer/T-cell lymphoma, nasal type, with a 22year indolent clinical course. Am J Dermatopathol. 2012; 34: 194-7. PMid: 22172956. http://dx.doi.org/10.1097/DAD.0b013e3 18230 ee 41

[10] Kim HJ, Kim SH, Oh SH. CD56-negative extranodal NK/T-Cell Lymphoma, nasal type, with extranasal cutaneous involvement. Ann
Dermatol. 2015; 27: 618-20. PMid: 26512181. http://dx.doi.o $\mathrm{rg} / 10.5021 / \mathrm{ad} .2015 .27 .5 .618$

[11] Wang TT, Xu C, Liu SL, et al. Clinicopathology, immunophenotype, $\mathrm{T}$ cell receptor gene rearrangement, Epstein-Barr virus status and p53 gene mutation of cutaneous extranodal NK/T-cell lymphoma, nasal-type. Chin Med J. 2013; 126: 1281-7.

[12] Li S, Feng X, Li T, et al. Extranodal NK/T-cell lymphoma, nasal type: a report of 73 cases at MD Anderson Cancer Center. Am J Surg Pathol. 2013; 37: 14-23. PMid: 23232851. http://dx.doi.org/1 $0.1097 /$ PAS. Ob013e31826731b5

[13] Lee WJ, Lee $\mathrm{MH}$, Won $\mathrm{CH}$, et al. Comparative histopathologic analysis of cutaneous extranodal natural killer/T-cell lymphomas according to their clinical morphology. J Cutan Pathol. 2016; 43: 324-33. PMid: 26695102. http://dx.doi.org/10.1111/cup. 12660

[14] Lee WJ, Lee YJ, Won CH, et al. The applicability and prognostic value of the TNM classification system for primary cutaneous lymphomas other than mycosis fungoides and Sézary syndrome in primary cutaneous NK/T-cell lymphoma patients. J Am Acad Dermatol. 2015; 73: 172-4. PMid: 26089057. http://dx.doi.org/1 $0.1016 / j \cdot j$ jad. 2015.03.042

[15] Takata K, Hong ME, Sitthinamsuwan P, et al. Primary cutaneous NK/T-cell lymphoma, nasal type and CD56-positive peripheral T-cell lymphoma: a cellular lineage and clinicopathologic study of 60 patients from Asia. Am J Surg Pathol. 2015; 39: 1-12. PMid: 25188863. http://dx.doi.org/10.1097/PAS.0000000000000312

[16] Hamada T, Iwatsuki K. Cutaneous lymphoma in Japan: a nationwide study of 1733 patients. J Dermatol. 2014; 41: 3-10. PMid: 24438138. http://dx.doi.org/10.1111/1346-8138.12299

[17] Terada T, Kawaguchi M, Furukawa K, et al. Minute mixed ductalendocrine carcinoma of the pancreas with predominant intraductal growth. Pathol Int. 2002; 52: 740-6. PMid: 12685552. http: //dx.doi.org/10.1046/j.1440-1827.2002.01416.x

[18] Terada T, Kawaguchi M. Primary clear cell adenocarcinoma of the peritoneum. Tohoku J Exp Med. 2005; 206: 271-5. PMid: 15942157. http://dx.doi.org/10.1620/tjem.206.271

[19] Villamor N, Morice WG, Chan WC, et al. Chronic lymphoproliferative disorders of NK cells. In: Swerdlow SH, Campo E, Harris NL, Jaffe ES, Pileri SA, Stein H, Thiele J, Vardiman JW eds. WHO classification of tumours of haematologic and lymphoid tissues. Lyon: IARC Press; 2008. 274p.

[20] Chan JKC, Jaffe ES, Ralfkiaer E, et al. Aggressive NK-cell leukemia In: Swerdlow SH, Campo E, Harris NL, Jaffe ES, Pileri SA, Stein $\mathrm{H}$, Thiele J, Vardiman JW eds. WHO classification of tumours of haematologic and lymphoid tissues. Lyon: IARC Press; 2008. 276p. 